Rev. Dariusz Lipiec

The John Paul II Catholic University of Lublin

\title{
Pastoral Care of the Disabled in the Directory for Catechesis Published on March 23, 2020
}

The most recently published Directory for Catechesis addresses catechesis for the disabled within the totality of the Church's pastoral ministry. The dignity of every person as a child of God, which is granted through the Sacrament of Baptism when a person is incorporated into the Body of Christ, is the basis for the Church's pastoral care, which includes catechesis, of the disabled. The presence of the disabled within the ecclesial community and secular society is a gift, since such individuals enrich their environment and inspire others to perform good deeds. The disabled both receive and proclaim God's word just as they also share in the priestly ministry of the faithful and participate in the liturgy. However, it is important for the Church to adjust how She ministers to the disabled in order to meet their personal needs and abilities and to adapt Her approach properly to apostolic activity, especially giving witness by living a Christian life.

Key words: Directory for Catechesis, disability, pastoral care of the disabled, catechesis for the disabled.

The Pontifical Council for the Promotion of the New Evangelization's latest Directory for Catechesis discusses catechesis in modern world and is addressed primarily to catechists and those who study this manner of preaching the Good News. This document describes catechesis within the broader social and religious context of the present circumstances of life and the mission of the Church. The Council wrote this document in the light of contemporary social and religious changes that have taken place and the subsequent challenges that catechists now face. Catechesis is an integral part of Church's entire pastoral activity. It is also a way of proclaiming God's word, which is realized in the community of the Church as well as the sacraments, 
prayer, and ministry, which arise from Christian charity. This is how the Council perceives catechizing the disabled within a broader social and pastoral context.

\section{The bases of the Church's pastoral care of the disabled}

The Church's teaching regarding the disabled are incorporated into the Holy See's Directory for Catechesis. This teaching highlights that human dignity is an integral element of the pastoral care of those with motor, sensory, or intellectual limitations. This means that, despite their limitations, such individuals are fully human and equal to those without disabilities. ${ }^{1}$ A person's value is not determined by how efficient he is or by his human potential and self-realization, but rather by his dignity, which is an essential part of human nature. ${ }^{2}$ When $\mathrm{He}$

Pastoral Theology creates man, God endows him with this irrevocable dignity. As a result, every person, even those with disabilities, is a subject in his own life and has both the right and the obligation to participate actively in the life of the community and to contribute to it in his own proper and unique way. For the disabled, the circumstances and limitations that their disabilities impose are the only thing that limits this involvement. Disabled individuals, who God creates in His image and likeness, are His children who can enjoy His fatherly love just like those who are not disabled. ${ }^{3}$ God not only creates the disabled, He also redeems them through His Son's passion, death, and resurrection. As such, He invites them to cooperate in the salvation of the world. They are also welcomed to participate in the community of the saved. Having received the sacraments of Baptism and Confirmation, the disabled are enabled to live out their Christian and human vocation. The Christian vocation is the call to personal holiness. Although this vocation is bestowed on every person in the Sacraments of Christian Initiation, each person is called to grow in and respond to this gift. People with different disabilities are also called to cooperate with the Lord by living out this gift and becoming more like Him. Those who are bestowed with the gift of the Holy Spirit are called to live out their personal vocation. The Directory

$1 \quad$ See W. Chudy, "Sens życia a sens trudu. U podstaw rozważań problemu sensu życia osób niepełnosprawnych,"in: Osobyniepełnosprawnewżyciu społeczeństwa i Kościoła, eds. A. Bartoszek, D. Sitko, Tarnów 2003, 11-45.

2 See K. Bochenek, "Filozoficzne racje godności osobowej człowieka upośledzonego," in:Katecheza specjalna dzisiaj.Problemyi wyzwania, ed.J.Stala, Kielce 2003, 153-168.

3 “Dokument Stolicy Apostolskiej na Międzynarodowy Rok Osób Upośledzonych," Ateneum Kapłańskie 103(1984) fasc. 1: 9-11. 
for Catechesis highlights that God bestows on the disabled different types of particular vocations. They do not have to live in isolation; although, this way of life is also possible should they be called to it.

The dignity and subjectivity of those within the community of the Church also means that people with disabilities are called to the apostolate. Although the disabled have access to every possible type of apostolate, the most recent Directory for Catechesis stresses mainly two: The first is the apostolate of giving witness through their presence, and the second is the apostolate of the word. Due to the universal nature of the ecclesial document, it focuses on the ministry of proclaiming God's word. The document also emphasizes strongly the value of the disabled giving witness through their presence within the community because it inspires others to do good. In other words, when a weaker member of the community who needs assistance and support is present, then many people react spontaneously by providing the necessary help. This assistance is of great importance not only for the disabled person, but it also increases the sensitivity and humanity of the person who helps. In this way, the presence of the disabled has a positive influence on the formation of pro-social attitudes in members of society and elevates the level of a society's culture.

The personal witness of the disabled is another type of apostolate that the Directory for Catechesis mentions. Even the disabled are called to share their faith with others, which-as the document states-is the most valuable. The disabled live out their union with God in a direct and intuitive way. ${ }^{4}$ As a result, they can transmit their faith to others effectively. In fact, their witness is oftentimes more convincing than the witness of those who are healthy and abled.

The Holy See indicates that the gift of faith is necessary for the disabled to transmit their faith and the word of God. A person has this gift only if God bestows it on him. Therefore, it is important that the disabled have received the gift of faith as both as a deep bond with God and in its contents. In this way, the disabled are recipients of the pastoral care of the community of the Church, which is entrusted with the responsibility of passing on to them the gift of faith. Catechesis is an important means to transmit the faith because through its multifaceted impact it introduces individuals into the communion with God, it helps them deepen their bond with the Lord, and promotes a better understanding of Him.

$4 \quad$ See Pontifical Council for the Promotion of the New Evangelization, Directory for Catechesis, Vatican City 2000, 271. (Abbreviated hereafter as Directory). 


\section{The disabled are a gift to the Church and society}

The most recent Directory for Catechesis states unequivocally that "persons with disabilities must be welcomed as a great gift." 5 This attitude toward the physically and mentally disabled results from understanding what it means to be disabled. Disabilities are often perceived as a burden, suffering, loss, or even a punishment from God. People with disabilities perceive themselves as being different from others in a negative way. They perceive themselves and their future perspectives as worse in comparison to others and, therefore, feel wronged, unhappy, and less able to experience self-fulfilment, success, and happiness according to their environment's definition of happiness.

This perception of disability and the disabled is, unfortunately, common not only among the disabled but also among those within society. Although the disabled are seen in public, many people do not

Pastoral Theology

have direct contact with them. Since the disabled are different, people often misunderstand them. Conversely, lack of knowledge about disabilities subsequently leads people to feel insecure or even afraid to interact with the disabled. People also feel embarrassed by their lack knowledge about different types and degrees of disabilities and how they affect the disabled. Often a lack of knowledge regarding how to act around the disabled, especially when their disability is permanent or long-term, leads to prejudice, social distancing, and, eventually, their marginalization and social exclusion. ${ }^{6}$ Because the Directory for Catechesis presents disability as a gift, those on whom this gift has been bestowed are a gift to the Church and society. Perceiving disability as a gift to the disabled and society may be difficult to accept for the disabled and the communities in which they live. The directory does not discuss rehabilitating the disabled or the issue of helping them accept their condition. Rather, it focuses on the community, particularly its acceptance of the disabled, which leads to their full inclusion in the Church and society.

The Directory for Catechesis presents why people with disabilities are a gift to the Church and society. One reason is the fact that they witnesses to the truth about the fragility of human existence. Even though they are consider weaker than abled people according to a human way of thinking, their weakness points to the weakness of human nature and of the existence that all people on earth share. In reality,

Ibid., 270.

6 SeeA.Bartoszek, "Niepełnosprawność osóbjako wyzwanie moralne,"in: Osoby niepetnosprawne w życiu społeczeństwa i Kościoła, eds. A. Bartoszek, D. Sitko, Tarnów 2003, 63-90. 
every person is "disabled," meaning physically, mentally, or spiritually weak in God's eyes due to the limitations and imperfections of human nature that are the consequence of original sin. Every person struggles to some degree with imperfections and weaknesses in the pursuit to conform to God's image. Life is the process of transcending one's weaknesses and limitations. The disabled, who are considered weaker and less perfect than others, are a salutary reminder of the need to transcend one's limitations and strive for moral perfection. Their attitude serves as an example and proof that, in Christ, transcending one's limitations is possible for every person.

Another reason why people with disabilities are a gift to the Church and society is because union with Christ has apostolic value. The $D i$ rectory for Catechesis recalls that modern individuals try to create a culture that avoids both suffering and even speaking about it in the public sphere. In reality, suffering affects part of every person's life and social life. Attempts to avoid suffering are not always effective, which is especially true because suffering often occurs regardless of whether or not a person wills it. Disability, however, is not a good in itself; it indicates the absence of something good and entails different kinds of suffering. For this reason, it is necessary to accept disabilities at least to the degree to which it enables the disabled individual to be rehabilitated. ${ }^{7}$ The Holy See's document indicates that such acceptance is possible by uniting one's suffering with Christ's suffering. Christ's suffering as He died on the cross has inestimable value; for, man's salvation would have been impossible without it. When a disabled person unites his or her suffering to Christ's, this transforms the person and he or she becomes conformed to Christ the Saviour, which imbues the person's own suffering with the power of salvation. In this way, the disabled person does not suffer in vain, which would only diminish him, and becomes conformed to Christ, which fosters growth and development. The presence of the disabled within the Church and society serves as a witness that fosters the acceptance of suffering in individual lives and in society and the discovery of its meaning in the development of individuals and societies. Moreover, suffering is part of society and the Church community's mission to nurture an attitude of solidarity and provide sufficient and effective help to those with disabilities.

See M. Plura, "Rola osób niepełnosprawnych w społeczeństwie," in: Etyczne i duchowe potrzeby osób niepetnosprawnych, eds. R. Buchta, K. Sosna, Katowice 2007, 115-119. 
Pastoral Theology

\section{An inclusive culture and proclaiming God's word}

Inclusion of the poor, which is characteristic of Pope Francis' teaching, is reflected in the latest Directory for Catechesis. The Pope includes the disabled among the poor because he considers poverty to be not only a lack of material goods necessary to live, but also the absence anything that limits and marginalizes people. The culture of inclusion discussed in the Holy See's document supports including the disabled in social and ecclesial life. According to Pope Francis, the disabled should be treated like those who are not disabled, and he encourages Church or social community members to help them in such a way that gives them their due place among others. ${ }^{8}$

With regard to proclaiming the Good News, the Directory for Catechesis dedicates a section to the disabled. The document reminds readers that the disabled are capable of making acts of faith. Even those who are intellectually disabled are endowed with a sense of faith. Even though this sense is based more on intuition than the intellect, depending upon the degree of the disability, God calls every disabled person to have faith and live in the community of believers. ${ }^{9}$ Therefore, a catechesis that seeks to lead those with disabilities to a personal encounter with God and to a deeper union with Him is necessary.

The Pontifical Council for the Promotion of the New Evangelization's document is firmly opposed to excluding the disabled from the Church's catechetical activity. Since the disabled are God's children and members of the Church community called to salvation, and because they are capable of having personal faith, their presence in catechetical ministry should be considered completely normal. In such a way the Directory for Catechesis rejects the idea that people with disabilities, especially intellectual, are not capable of participating in catechesis because they are unable to grow in faith. Furthermore, it opposes any apparent negligence that would cause the disabled not to participate in catechesis.

The authors of the Directory for Catechesis are aware of specific aspects of being disabled and its influence on those who suffer from

8 See A. Krauze, "Współczesne tendencje w procesie rewalidacji osób niepełnosprawnych - normalizacja," in: Katecheza specjalna dzisiaj. Problemy i wyzwania, ed. J. Stala, Kielce 2003, 297-316.

$9 \quad$ See A. Bartoszek, "Przeżywanie wiary oraz wartości moralnych we wspólnocie osób niepełnoprawnych umysłowo. W oparciu o doświadczenia Ośrodka dla Niepełnosprawnych 'Najświętsze Serce Jezusa' w Rudzie Śląskiej,” in: Osoby niepełnosprawne w życiu społeczeństwa i Kościoła, eds. A. Bartoszek, D. Sitko, Tarnów 2003, 209-221. 
it. They also understand that people with disabilities are not able to participate in catechesis in the same way as others. For this reason, they provide set of indications and pastoral requirements that will enable people with disabilities to participate in catechesis as well as more effective ways for catechists to proclaim the word of God to them. The directory's basic indication is to involve the disabled in catechetical programs. The director also states the locations and circumstances in which to include people with disabilities in catechesis. In countries where Christian tradition is still very strong and where pastoral care is well developed, the disabled are included in catechetical programs. Cases where the disabled are excluded from programs occur very rarely and are considered the exception. In missionary countries, however, the situation is different. In these countries, catechesis is rather general in nature and seldom tailored to the needs of minority groups among the faithful. The teaching of the Holy See urges the development of special catechesis that takes into account and is tailored to the kind of disability and severity of those who are disabled.

The Directory for Catechesis highlights the need to prepare catechetical programs that are suited to the spiritual needs and abilities of people with disabilities. It is particularly important to "seek new channels of communication and methods more suitable for fostering an encounter with Jesus..$^{10}$ Although the document does not state this outright, it is indirectly suggests (as has been stated already in other Church documents on this topic) that catechists and others should consider to scientific findings and research that pertain disabilities in order to help the disabled understand catechesis better and, thereby, facilitate the catechesis. The document emphasizes the need to understand the specifics of particular disabilities in order to meet the disabled's particular needs, thus implying that catechists need to provide an individualized approach for every disabled person. According to the document, " $\mathrm{i}[\mathrm{t}]$ is therefore useful to employ experimental dynamics and languages that involve the five senses and narrative methods capable of involving all the participants in a personal and meaningful way." 11 The Directory for Catechesis also indicates the importance of working with the families of those who are being catechized. This is especially important in the case of the disabled, because it is usually

10 See A. Kiciński, Katecheza osób z niepetnosprawnościa intelektualna, Lublin 2007, 327-376. 
Pastoral Theology

necessary for their family members to be involved in catechesis. ${ }^{12}$ By working together with families of the disabled, the catechist can provide more effective catechesis. In addition, family members of the disabled are frequently unable to provide the proper support and need the help of a catechist who can help them understand the specific needs and expectations of the disabled family member. In some cases, just like the disabled, their families are also marginalized or rejected. While accompanying such families, catechists can contribute to including them into the full participation in the life of society and the Church. ${ }^{13}$ Properly prepared catechists are necessary to implement such catechesis for the disabled. In this case, their pastoral duties extend far beyond their strictly catechetical ministry by requiring knowledge of psychology and pedagogy as well as pastoral skills to minister both to families and local communities. Such skills enable catechists to create and foster a culture of inclusion and provide effective assistance to the disabled and their families. ${ }^{14}$

\section{An inclusive culture and sacramental and prayer life}

The idea of including the disabled in the life of the Church community is also reflected in sacramental and prayer life. The Directory for Catechesis discusses including the disabled as participants in evangelization as well as educators in catechesis. The Holy See argues that all the people with disabilities are called to participate in sacramental life ${ }^{15}$ and subsequently dispels lingering doubts whether the disabled are capable of receiving the sacraments, especially those that require the recipient's conscious involvement. ${ }^{16}$ This doubt concerns primarily those who suffer from severe mental disability and receive the Holy

12 See K. Sosna, "Współpraca z rodzicami dzieci niepełnosprawnych umysłowo," in: W poszukiwaniu katechezy rodziców. Studium teoretyczno-empiryczne, eds. J. Stala, E. Osewska, Tarnów 2007, 367-374.

13 See B. Sidor, “Współpraca z rodzicami dzieci z niepełnosprawnością,” in: W poszukiwaniu katechezy rodziców. Studium teoretyczno-empiryczne, eds. J. Stala, E. Osewska, Tarnów 2007, 349-360.

14 See A. Kiciński, "Katecheta specjalny,”in: Katecheza specjalnadzisiaj.Problemy i wyzwania, ed. J. Stala, Kielce 2003, 39-54.

15 See K. Sosna, "Przygotowanie do Komunii Świętej osób niepełnosprawnych umysłowo w świetle dekretu Quam singularis," in: Eucharystia - pokuta i pojednanie. Problemy i wyzwania, ed. J. Stala, Kielce 2007, 235-244.

16 See D. Lipiec, "Kościół wobec zasady normalizacji sytuacji życiowej osób niepełnosprawnych,” in: Przestrzenie pracy socjalnej, ed. J. Stala, Tarnów 2010, 107-116. 
Eucharist and the Sacrament of Penance and Reconciliation. Previous popes have already resolved the debate on this subject, and the Holy See has clarified unclear issues.

The directory unequivocally repeats previous assertions that "[p]ersons with disabilities are called to the fullness of the sacramental life, even in the presence of severe disorders. [...] therefore no one can refuse the sacraments to person with disabilities."17 The document goes on to explain the logic behind this decision: "The sacraments are gifts from God, and the liturgy, even before being rationally understood, needs to be lived." 18 This reasoning is based on the teaching that God gives man the sacraments in order for him to grow and develop. The sacraments, therefore, should not be regarded as a reward for meeting certain conditions or criteria. This gift also arises from man's inborn dignity as a child of God: whether disabled or abled, God bestows on all people the fullness of humanity and offers them the sacraments. By stating that "the liturgy [...] needs to be lived," the Pontifical Council for the Promotion of the New Evangelization highlights the primary importance of the existential meaning of faith, which involves "clinging" to God and uniting one's life to His. Every man is capable of inviting God into his life and developing personal relationship with Him, even those who are intellectually disabled. The statement that "the liturgy, even before being rationally understood, needs to be lived" does not exclude the faithful's need to deepen their awareness and understanding of the sacraments and to receive them. The document points out that the disabled, especially those with intellectual limitations, should not be treated in the same way as those without disabilities because the disabled are not able to meet certain conditions. This concerns both preparation for and the reception of the sacraments.

In order to properly understand the Church's teaching regarding intellectual preparation for the reception of the sacraments, Directory for Catechesis indicates that a sacramental catechesis tailored to the disabled needs to be prepared and introduced. Intellectual disability does not exclude the disabled from understanding to a certain extent what sacraments are and their role in Christian life. Therefore, sacramental catechesis is necessary and should be adapted to the cognitive abilities of the intellectually disabled.

The idea of including the disabled in sacramental life and prayer has a communal dimension. The Directory for Catechesis highlights the personal contribution that the disabled make to the liturgy of the

$17 \quad$ See Directory, 272.

18 Ibid. 
ecclesial community. The document recalls that others can discover the joy and beauty of faith because of the disabled. The faith of people with disabilities, especially of those with intellectual disabilities, is often based on a natural spontaneity. Many of the disabled are incapable of feigning acts of faith, and it is clear that when they do make such acts, they arise from their hearts. This natural beauty of faith that is professed authentically has the power to enrich individuals and the entire Church community. ${ }^{19}$ Therefore, the Holy See encourages Church communities to openly include the disabled in the Church's liturgy and prayer, especially Sunday Mass, which is the source and summit of the faith in the lives of the faithful and the community. The testimony of the faithful, which the disabled express in an authentic and convincing way, has its source in the liturgy. ${ }^{20}$

Pastoral Theology

\section{Conclusion}

With regard to the disabled, the most recently published version of the Directory for Catechesis focuses on embracing everyone, which leads to promoting a culture of inclusion. This approach is based on the truth that God bestows human dignity on the disabled who are redeemed by Christ and called to participate in Christian life in all its fullness. The document opposes excluding the disabled both socially and from the Church and promotes giving them their proper place in the human and ecclesial community by allowing them to be involved personally in the life of the community. Although it is devoted to catechesis, the Holy See's document addresses the issue of those to be catechized within the broader context of their religious life and catechesis as an aspect of the Church's pastoral ministry. The document also provides a better understanding the Church's stance regarding the disabled and their disabilities.

\section{Bibliography:}

1. Bartoszek, A. "Niepełnosprawność osób jako wyzwanie moralne.” In: Osoby niepełnosprawne w życiu społeczeństwa i Kościoła. Edited by A. Bartoszek, D. Sitko. Tarnów 2003, 63-90.

19 See D. Jucha, "Wspólnota wobec katechizacji osób upośledzonych umysłowo," in: Katecheza specjalna dzisiaj. Problemy i wyzwania, ed. J. Stala, Kielce 2003, 187-206.

20 See I. Celary, "Kształtowanie postaw duchowych i liturgicznych u dzieci niepełnosprawnych," in:Dialog zosobami niepetnosprawnymi, ed.Z. Brzezinka, Katowice 2004, 51-57. 
2. Bartoszek, A. "Przeżywanie wiary oraz wartości moralnych we wspólnocie osób niepełnoprawnych umysłowo. W oparciu o doświadczenia Ośrodka dla Niepełnosprawnych 'Najświętsze Serce Jezusa' w Rudzie Śląskiej." In: Osoby niepetnosprawne $w$ życiu społeczeństwa $i$ Kościoła. Edited by A. Bartoszek, D. Sitko. Tarnów 2003, 209-221.

3. Bochenek, K. "Filozoficzne racje godności osobowej człowieka upośledzonego." In: Katecheza specjalna dzisiaj. Problemy i wyzwania. Edited by J. Stala. Kielce 2003, 153-168.

4. Celary, I. "Kształtowanie postaw duchowych i liturgicznych u dzieci niepełnosprawnych." In: Dialog z osobami niepełnosprawnymi. Edited by Z. Brzezinka. Katowice 2004, 51-57.

5. Chudy, W. "Sens życia a sens trudu. U podstaw rozważań problemu sensu życia osób niepełnosprawnych." In: Osoby niepetnosprawne $w$ życiu społeczeństwa i Kościoła. Edited by A. Bartoszek, D. Sitko. Tarnów 2003, 11-45.

6. “Dokument Stolicy Apostolskiej na Międzynarodowy Rok Osób Upośledzonych." Ateneum Kapłańskie 103(1984) fasc. 1: 8-19.

7. Jucha, D. "Wspólnota wobec katechizacji osób upośledzonych umysłowo." In: Katecheza specjalna dzisiaj. Problemy i wyzwania. Edited by J. Stala. Kielce 2003, 187-206.

8. Kiciński, A. "Katecheta specjalny." In: Katecheza specjalna dzisiaj. Problemy $i$ wyzwania. Edited by J. Stala. Kielce 2003, 39-54.

9. Kiciński, A. Katecheza osób z niepetnosprawnością intelektualną. Lublin 2007.

10. Krauze, A. "Współczesne tendencje w procesie rewalidacji osób niepełnosprawnych - normalizacja." In: Katecheza specjalna dzisiaj. Problemy i wyzwania, Edited by J. Stala, Kielce 2003, 297-316.

11. Lipiec, D. “Kościół wobec zasady normalizacji sytuacji życiowej osób niepełnosprawnych.” In: Przestrzenie pracy socjalnej. Edited by J. Stala. Tarnów 2010,107-116.

12. Pontifical Council for the Promotion of the New Evangelization. Directory for Catechesis. Vatican City 2020.

13. Plura, M. "Rola osób niepełnosprawnych w społeczeństwie.” In: Etyczne i duchowe potrzeby osób niepetnosprawnych. Edited by R. Buchta, K. Sosna. Katowice 2007, 115-119.

14. Sidor, B. "Współpraca z rodzicami dzieci z niepełnosprawnością." In: W poszukiwaniu katechezy rodziców. Studium teoretyczno-empiryczne. Edited by J. Stala, E. Osewska. Tarnów 2007, 349-360.

15. Sosna, K. "Przygotowanie do Komunii Świętej osób niepełnosprawnych umysłowo w świetle dekretu Quam singularis." In: Eucharystia - pokuta i pojednanie. Problemy i wyzwania. Edited by J. Stala. Kielce 2007, 235-244.

16. Sosna, K. "Współpraca z rodzicami dzieci niepełnosprawnych umysłowo." In: W poszukiwaniu katechezy rodziców. Studium teoretyczno-empiryczne. Edited by J. Stala, E. Osewska. Tarnów 2007, 361-374. 